\title{
Whither International Law? Security Certificates, the Supreme Court, and the Rights of Non-Citizens in Canada
}

\author{
Graham Hudson
}

Abstract

In this paper, the author examines the role of international law on the development of Canada's security certificate regime. On the one hand, international law has had a perceptible impact on judicial reasoning, contributing to judges' increased willingness to recognize the rights of noncitizens named in certificates and to envision better ways of balancing national security and human rights. On the other hand, the judiciary's attitudes towards international law as non-binding sources of insight akin to foreign law has reinforced disparities in levels of rights afforded by the Canadian Charter of Rights and Freedoms and those afforded by international human rights. Viewed skeptically, one might argue that the judiciary's selective resultoriented use of international law and foreign law helped it spread a veneer of legality over an otherwise unaltered and discriminatory certificate regime. Reviewing Charkaoui I and II in international context, the author suggests an alternative account. He suggests that the judiciary's use of international law and foreign law, although highly ambiguous and ambivalent, both was principled and has progressively brought named persons' Charter rights more closely in step with their international human rights. Although the current balance between national security and human rights is imperfect, the way in which aspects of Canada's certificate regime have been improved suggests that international law is a valuable resource for protecting the rights of non-citizens in Canada.

\section{Résumé}

Dans cet article, l'auteur examine le rôle du droit international sur le développement du régime canadien de certificats de sécurité. D'une part, le droit international a eu un impact perceptible sur le raisonnement judiciaire, contribuant à une volonté accrue chez les juges de reconnaître les droits de non citoyens visés par les certificats et d'envisager de meilleurs moyens de concilier la sécurité nationale et les droits de la personne. D'autre part, l'attitude de la magistrature à l'égard du droit international comme source non contraignante d'éclairement apparentée à la jurisprudence étrangère est venue renforcer la disparité entre la protection conférée par la Charte canadienne des droits et libertés et celle offerte par le droit humain international. Avec scepticisme, on pourrait soutenir que l'utilisation sélective, axée sur les résultats que fait la magistrature du droit international et de la jurisprudence étrangère camoufle sous un vernis de légitimité un régime de certificat par ailleurs intact et discriminatoire. Situant les décisions de la cour dans l'affaire Charkaoui dans un contexte international, l'auteur suggère une autre lecture: l'utilisation qu'a fait la magistrature du droit international et étranger, bien que très ambiguë et ambivalente, était régie par des principes et a progressivement rapprocher les droits des individus sous la Charte de leurs droits humains internationaux. Bien que l'équilibre actuel entre la sécurité nationale et les droits de l'homme soit imparfait, la manière dont certains aspects de notre régime des certificats ont été améliorés suggère que le droit international est une ressource précieuse pour la protection des droits de non citoyens au Canada.
A nyone interested in whether international law improves respect for non-citizens' rights in Canada would do well to survey the post-9/11 development of Canada's security certificate regime. First established in 1976, security certificate legislation authorizes the executive to arrest, detain, and ultimately deport non-citizens who are believed on reasonable grounds to, among other things, 
pose a threat to Canadian national security. Certificates are issued by the Ministers of Public Safety and of Citizenship, Immigration, and Multiculturalism (the ministers) without any prior independent review, while significant portions of proceedings concerning the reasonableness of certificates and conditions of detentions are held in the absence of the public, persons named in certificates (named persons), and their counsel.

In Charkaoui $I,{ }^{1}$ the Supreme Court (the Court) ruled that aspects of certificate provision violated the Canadian Charter of Rights and Freedoms (the Charter), breaking with courts' traditional reluctance to do so. ${ }^{2}$ Relying on international law and foreign law, the Court found that extreme secrecy and executive discretion unjustifiably infringed named persons' right to a fair trial. Although the Court based its decision on long-standing Canadian criminal law principles, international law and foreign law supported its finding that the government could have achieved a more proportionate ways of balancing national security and human rights. In suggesting how to achieve this balance, the Court looked to analogous national security legislation in the United Kingdom, noting that it had been designed to (although it does not) comply with international human rights. It then suggested that adopting this system in Canada would bring certificate provisions into conformity with the Charter.

Acting on the Court's advice, Parliament integrated a version of the UK's special advocate system into the Immigration and Refugee Protection $\mathrm{Act}^{3}$ (IRPA), providing named persons with limited legal representation during secret hearings. In addition to introducing a special advocate system, Parliament made it easier for named persons to procure conditional release pending a decision as to the reasonableness of the certificates against them; to appeal decisions about detentions and the reasonableness of certificates; to apply for protection as refugees or persons in similar situations; and to challenge the admissibility of evidence on the grounds that it has been acquired through the use of torture or other cruel, inhuman, or degrading treatment or punishment. ${ }^{4}$ It would appear that the Court effectively used international law to expand the rights to which noncitizens are entitled.

However, a closer look suggests that international law has played a far more ambivalent and ambiguous role. On the one hand, the Court in this case curtly ignored powerful international legal arguments concerning the discriminatory nature of certificate provisions, a confusing choice considering its willingness to use international law when forming its judgment on issues of fairness, disclosure, and adversarial challenge. Far from simply producing mixed messages about the place of international law in Canadian courtrooms, this choice permitted the government to continue using immigration law provisions to perform quasi-criminal law functions. On the other hand, when international law was used, it was conflated with foreign law, as though the obligatory qualities of the former do not matter. In this case, the failure to distinguish international law from foreign law facilitated the entrenchment of a special advocate system the Court knew fell below international human rights standards. ${ }^{5}$ In suggesting that this system would nonetheless pass Canadian constitutional muster, the Court seemed to have sent the government a message concerning how the form of certificate provisions could be altered without adversely affecting their overall function. The message was loud and clear: the Charter does not provide protections at least as great as those offered by international human rights.

Adding to the Court's inconsistent stance towards international law is its 2008 judgment in Charkaoui II. ${ }^{6}$ Concerned with issues of disclosure directly relevant to those raised in Charkaoui $I$, the Court in this case ruled the government is required to retain and disclose to judges and special advocates all information on file relevant to a named person. Although the facts of this case concerned, among other things, the human rights dimensions of global intelligence agency co-operation, the Court did not cite international law even once. Yet, by forcing greater levels of disclosure, the decision helped remedy some of the more serious defects of the new special advocate system, effectively bringing it more closely in step with those international human rights standards the Court declined to fully enforce in Charkaoui I. What, if anything, influenced the Court's choices about whether, how, or why to use international law in these cases? Did it take seriously its role in giving effect to binding international law? If so, how did this affect its decision about the appropriate balance between national security and human rights?

The purpose of this paper is to sketch how international law has influenced court-led refinements to the security certificate regime. My focus will be directed primarily towards international human rights, although I will also recognize the place and impacts of other fields of international law. I will argue that, although its reasoning has been highly ambiguous and ambivalent, the Supreme Court's consideration of international law has contributed to marked improvements in the protection of named persons' rights. I will begin by looking at the legislative and the international contexts of certificate provisions. I will then examine how the Court used international law in Charkaoui I to bring certificate provisions into conformity with the Charter. After reviewing the many ways in which the government's legislative response failed to respect international human rights, I look at how these failings were compensated for in

(C) Graham Hudson, 2009. This open-access work is licensed under a Creative Commons Attribution-NonCommercial 4.0 International License, which permits use, reproduction and distribution in any medium for non-commercial purposes, provided the original author(s) are credited and the original publication in Refuge: Canada's Journal on Refugees is cited. 
Charkaoui II. I will conclude by offering an interpretation of how international law has affected the recognition of named persons' rights.

\section{Legislative Context: The "Old" Certificate Provisions}

Prior to Charkaoui I, security certificates were issued under the joint powers of the Ministers of Citizenship and Immigration and of Public Safety and Emergency Preparedness $^{7}$ and were issued against non-citizens who were alleged to be inadmissible to Canada on the grounds of national security, the violation of international human rights, serious criminality, or organized crime. ${ }^{8}$ Although foreign nationals could be detained without warrant, the ministers were required to issue a warrant in order to detain permanent residents. ${ }^{9}$ Once detained, the ministers were required to refer the certificate and the evidence supporting its reasonableness to a Federal Court judge for review. Although there was no statutory obligation to make this referral within any specified period of time, the ministers generally did so shortly after detaining a named person. If found to be reasonable, the certificate stood as conclusive proof that the person named in it is inadmissible to Canada and stood as an effective removal order. ${ }^{10}$

Foreign nationals and permanent residents possessed markedly different rights while awaiting decisions about the reasonableness of a certificate. Foreign nationals were allowed to apply for a review of their detention only 120 days after a certificate had been found to be reasonable. Permanent residents, by contrast, had the right to a hearing before a judge within forty-eight hours of their being detained and once every six months after that point, up to and following a finding that the certificate was reasonable. ${ }^{11}$ Although judges had the discretion to order the conditional release of foreign nationals and permanent residents, the factors that constrain the exercise of this discretion were not outlined in IRPA or its regulations.

Certificate proceedings were designed to operate with little regard for values of fairness, disclosure, or adversarial challenge. Reviewing judges were instructed to conduct proceedings "as informally and expeditiously" as possible; to receive into evidence anything that, in their opinion, is reliable and appropriate, even if it is inadmissible in a court of law; and to base their decisions on that evidence. ${ }^{12}$ At the request of the ministers, judges were required to hear evidence in the absence of the public, the named person, and his/her counsel, if they were satisfied that the disclosure of such evidence would be injurious to national security or the safety of any person. ${ }^{13}$ Finally, named persons were not provided with a statutory right to appeal decisions about either the reasonableness of certificates or their detention.
Certificate proceedings are similar to criminal proceedings in a number of ways. First, decisions about whether to issue them are made by the executive branch in consideration of information produced by a range of both civilian intelligence and law-enforcement agencies. Second, unlike standard immigration law proceedings that are decidedly more administrative in nature, certificate proceedings are presided over by a Federal Court judge. Third, and most clearly, named persons are arrested and detained indefinitely pending the outcome of proceedings.

Finally, if reasonable, certificates generally authorize the government to deport named persons to face arrests, detentions, criminal or military trials, and the serious risk of severe human rights abuses. There is no necessary connection between certificate-based deportations and the commencement of public prosecutions or human rights abuses abroad. However, given the nature of international counterterrorism law and policy, there almost always is a practical connection. ${ }^{14}$ Named persons tend to be persons of interest to receiving states because, as alleged terrorists or serious criminals, they are viewed either as security risks by their home country or as sources of valuable information by partner states. Depending on levels of rights respect within their home countries, the deportation of named persons may expose them to the serious risk of persecution, torture, or other cruel, inhuman, and degrading treatment or punishment.

Despite the functional associations between certificate proceedings and criminal/extradition proceedings, principles germane to the latter were not legislatively integrated into the former, an omission Canadian courts had on a number of occasions ruled was constitutional. ${ }^{15}$ Judicial reluctance to force improvements in levels of rights respect were influenced by formal distinctions between immigration/administrative law and criminal law, the weight of national security rhetoric, and the belief that non-citizens are not entitled to as full a range of rights as are citizens. Still, a modicum of procedural protection was provided in the form of a named persons' statutory right to be reasonably informed of the case against them and to be heard. ${ }^{16}$ To these ends, judges provided named persons with summaries of the evidence that they had heard in private.

Like all non-citizens facing deportation, named persons also could apply for protection from the Minister of Citizenship and Immigration on the grounds that their deportation would expose them to the substantial risk of torture or similar abuse; claims of ordinary refugee status were barred, arguably consistent with international law recognizing national security as constituting, under the right circumstances, an exception to governments' obligation to protect Convention refugees. ${ }^{17}$ Although a step in the right

(C) Graham Hudson, 2009. This open-access work is licensed under a Creative Commons Attribution-NonCommercial 4.0 International License, which permits use, reproduction and distribution in any medium for non-commercial purposes, provided the original author(s) are credited and the original publication in Refuge: Canada's Journal on Refugees is cited. 
direction, rules governing applications for protection from torture or similar abuse had the effect of halting security certificate proceedings and could not be made once a certificate had been found to be reasonable, ${ }^{18}$ a strange provision considering that the risk of named persons' being exposed to human rights abuses increases after being labelled a de jure security threat.

\section{International Perspectives and Avenues of Influence}

Broadly speaking, there are two international perspectives that shape the interpretation and application of certificate provisions: international counterterrorism law and international human rights. On the one hand, a core objective of IRPA is to "promote international justice and security by denying access to Canadian territory to persons, including refugee claimants, who are security risks or serious criminals." 19 This objective is premised on states' internationally recognized right to exclude non-citizens from their territory ${ }^{20}$ and on Canada's expanding international legal obligations to co-operate in the prevention and punishment of transnational terrorism. ${ }^{21}$ Immigration officers, judges, and other decision-makers are accordingly required to interpret and apply certificate provisions so as to give effect to these international legal norms. While certificate provisions have been in existence since 1976, their operation is in this way amenable to shifts in international law and politics. Indeed, this is one of the reasons why post- $9 / 11$ counterterrorism law and policy has had such a profound impact on certificate proceedings despite the fact that the basic framework of Canada's current regime was constructed several months prior to $9 / 11$.

On the other hand, Canada has accepted a fairly wide range of international human rights obligations that should similarly influence the interpretation and operation of IRPA. In addition to international customary law, Canada is obligated to respect such treaties as the United Nations Convention relating to the Status of Refugees and the International Convention Against Torture $(C A T){ }^{22}$ International human rights are infused directly into certificate proceedings by way of s. 3(3)(f) of IRPA, which requires judges and other decision-makers to construe and apply the Act in a manner that consists with Canada's international human rights obligations.

It is important to recognize that these legislative provisions, and the international legal norms they recognize, apply only to the interpretation and application of IRPA. The constitutional dimensions of certificate provisions, by contrast, are matters of constitutional law and, for purposes of this paper, the Charter of Rights and Freedoms. However, unlike the constitutional documents of some other common law jurisdictions (and unlike IRPA), ${ }^{23}$ the Charter does not outline whether, how, or why judges may use international law when interpreting and applying its provisions. Precisely how international law can or should factor into the judicial review of certificate provisions is consequently ambiguous.

Traditionally, judges adhered to what might be called the "presumption of conformity" doctrine when deciding about whether to receive international law. This doctrine stands for the principle that judges will, absent clear evidence to the contrary, presume that legislatures intend for statutes to conform with Canada's international legal obligations and will interpret legislation accordingly. ${ }^{24}$ The purpose of this doctrine is as its name implies: to ensure conformity between domestic law and Canada's international legal obligations. It is, in other words, a tool by which the judiciary can help secure compliance with international law and which depends on the recognition of international law as law and not mere rhetoric or window dressing. However, because legislatures are free to legislate contrary to international law if they so choose, judges have only a limited role as enforcers. Indeed, they have tended to be conservative, using international law to refine or touch up legislation but not as an independent source of domestic rights and obligations. And, because this doctrine predated the Charter by decades, its use has generally been restricted to the interpretation of ordinary statutes and not the review of law or policy for consistency with constitutional rights.

Recently, this doctrinal landscape has changed and, with it, the place of international law in the context of Charter litigation. In 1987, Brian Dickson C.J. held that:

\footnotetext{
... the Charter should generally be presumed to provide protection at least as great as that afforded by similar provisions in international human rights documents which Canada has ratified.
}

In short, though I do not believe the judiciary is bound by the norms of international law in interpreting the Charter, these norms provide a relevant and persuasive source for interpretation of the provisions of the Charter, especially when they arise out of Canada's international obligations under human rights conventions. $^{25}$

There are at least two doctrines that may be extracted from this passage. ${ }^{26}$ First, there is the presumption of minimal protection doctrine, whereby international law serves as a floor below which no Canadian law may fall. Practically, what happens is the following. During the course of Charter litigation, legal counsel for one party must establish the existence of a right at international law. If it is demonstrated that this right exists and is binding on Canada, then judges

(C) Graham Hudson, 2009. This open-access work is licensed under a Creative Commons Attribution-NonCommercial 4.0 International License, which permits use, reproduction and distribution in any medium for non-commercial purposes, provided the original author(s) are credited and the original publication in Refuge: Canada's Journal on Refugees is cited. 
are presumptively obligated to enforce it. Opposing counsel must then somehow rebut this presumption in order to justify the limitation of the right. Thus, while judges are not obligated to independently or proactively consider international law, they are obligated to protect any undefeated international right established by counsel during the course of Charter litigation.

Second, there is the relevant and persuasive doctrine, whereby international law serves as a source of insight or perspective that helps judges resolve problems with complex international or transnational dimensions. ${ }^{27}$ The idea here is that international law connects decision-makers from various jurisdictions towards a common set of principles that offer potential solutions to recurring problems. Judges are free to pick and choose those rules and principles they think help construct the best approach to the issues they face. Unlike the presumption of conformity doctrine, the relevant and persuasive doctrine is not directed towards enforcing international law; its core concern is with improving the quality of judgment as measured in part by its responsiveness to diverse social identities, interests, and expectations. What is more, on this reading, judges are not obligated to recognize the relevance or applicability of international legal arguments. It is up to judges to decide what international legal norms are relevant to a dispute, in consideration of the fact that specifically international human rights law is always presumptively relevant and persuasive in the adjudication of constitutional rights.

It is generally agreed that the relevant and persuasive doctrine has become the most commonly used of the three approaches, although it uneasily coexists with the other two doctrines. ${ }^{28}$ Aside from the tremendous confusion this mixture of doctrines produces, the relevant and persuasive doctrine is, seemingly, inherently unpredictable. Insofar as the interpretive utility of international law is a matter of judicial discretion, it is not clear what factors determine whether, how, or why international law will be used; judges are free to arbitrarily pick and choose norms that help them rationalize decisions made on other grounds altogether. ${ }^{29}$ Insofar as international law serves in this way as a mere rhetorical device, its status as binding law is in danger of being lost. Some suggest that judicial discretion in this area may be exercised on the basis of a global judicial identity and commitment to the rule of law, such that judges from various jurisdictions extrapolate from each other's decisions a common body of legal rules and principles. ${ }^{30}$ These bodies of law exert a normative influence or pull similar to precedent, guiding judges towards the "best" possible solution to recurring global problems. In this way, the use of international legal norms, even merely as relevant and persuasive sources of insight, is principled.
Whatever may be its merits and demerits, the relevant and persuasive doctrine has both reflected and contributed to a considerable increase in judges' willingness to weave international law into their judgments, particularly in the context of Charter litigation. Combined with legislative directives to interpret and apply IRPA in consideration of Canada's international legal obligations, the judicial review of the constitutionality of certificate provisions has been steeped in international legal perspectives. How, if at all, have these perspectives influenced the development of Canada's certificate regime?

\section{International Law and Judicial Reasoning in Charkaoui I}

Charkaoui I concerned the appeals of three persons who were named in security certificates: Adil Charkaoui, Hassan Almrei, and Mohamed Harkat. Charkaoui was a permanent resident, Almrei and Harkat were foreign nationals, and all three were at one time recognized as Convention refugees. The appellants argued that the certificate scheme under which their detentions were ordered violated sections 7 (the right to life, liberty, and security of the person), 9 (the right to not be arbitrarily detained or imprisoned), 10 (c) (habeas corpus), 12 (the right not to be subjected to any cruel or unusual treatment or punishment), and 15 (the right to equality and to be free from discrimination) of the Charter.

International human rights do not appear to have directly influenced the Court's s. 7 analysis. The Court instead relied upon fairly standard English common law doctrines in finding that s. 7 affords named persons the right to a fair hearing, which includes the right to know the case against one, the right to answer that case, and the right to have that case judged on the basis of the facts and the law. ${ }^{31}$ Since named persons and their counsel were excluded from participating in substantial portions of certificate proceedings, since decisions could be made almost entirely on the basis of evidence that was withheld from named persons and their counsel, and since this limited judges' capacity to test the reliability, credibility, and sufficiency of that evidence, they were found to have been denied the right to a fair hearing.

The Court did rely upon international and foreign law when approaching the question of how the government's national security objectives could be more proportionately balanced with named persons's. 7 rights. After reviewing a number of Canadian alternatives, including the procedures utilized by the Security Intelligence Review Committee (SIRC) when it was responsible for testing the reasonableness of the ministers' allegations, ${ }^{32}$ the Court evaluated the UK's approach to secret national security proceedings. While this seems to signal the constructive use of international and foreign law, it was somewhat unnecessary since

(C) Graham Hudson, 2009. This open-access work is licensed under a Creative Commons Attribution-NonCommercial 4.0 International License, which permits use, reproduction and distribution in any medium for non-commercial purposes, provided the original author(s) are credited and the original publication in Refuge: Canada's Journal on Refugees is cited. 
the UK model was designed in the image of the SIRC model, but lacks many of its procedural safeguards. This raises the question of whether reliance on external legal perspectives served the interests of the appellants or the government. In approaching this question, it would be helpful to briefly highlight the movement of this institutional framework across jurisdictions.

Priori to 2001, SIRC was responsible for reviewing security certificates alleging the inadmissibility of non-citizens to Canada and for forwarding recommendations as to whether they thought the certificate was reasonable. The Minister of Citizenship and Immigration and the Solicitor General would then decide whether or not to issue the certificate. If they decided to issue the certificate against a permanent resident, they then had to refer it to a Federal Court judge for a review of its reasonableness.

Through the course of its investigations, SIRC utilized various kinds of legal counsel. Among those it used were security-cleared special advocates who enjoyed fairly broad powers to subpoena persons and documents, were permitted access to confidential, security-sensitive information, and were mandated both to challenge the non-disclosure of information and to cross-examine witnesses as to the relevance, reliability, and sufficiency of evidence. Special counsel were permitted to interact with named persons and their counsel throughout the process, including after having been apprised of secret evidence, and were permitted, in tandem with the Canadian Security Intelligence Service, to prepare and provide named persons with summaries of confidential information and evidence. Named persons were then allowed to provide special counsel with a list of questions to be asked during secret proceedings and to request that additional witnesses be called. ${ }^{33}$

In 1997, the UK integrated elements of the SIRC model into its own law because, one year earlier, the European Court of Human Rights (ECHR) ruled that the use of secret evidence, the absence of adequate legal representation, and the lack of meaningful judicial review, all in the context of national security proceedings, violated articles 5 (4) (right to challenge the lawfulness of detentions) and 13 (right to a remedy for breach of Convention rights) of the European Convention on Human Rights. ${ }^{34}$ Referencing the SIRC system, the ECHR held that the UK could have used less restrictive means to pursue its national security objectives, an example of how courts in other jurisdictions use something like the relevant and persuasive doctrine.

The UK subsequently designed a model in the image of SIRC, whereby a Special Immigration Appeals Commission utilized special advocates to represent named persons during secret proceedings. However, the UK chose not to include key protections characteristic of the SIRC system.
For instance, unlike special counsel for SIRC, special advocates operating within the UK system are not permitted, except under exceptional circumstances, to interact with named persons once they have been apprised of secret evidence or to subpoena witnesses and documents and were, at the time Charkaoui I was decided, severely under-staffed and -resourced. ${ }^{35}$ Special advocates have on a number of occasions stated that these limitations seriously inhibit their capacity to receive instructions from, and protect the interests of, named persons. ${ }^{36}$ These flaws, and possible solutions, have also been regularly identified by UK parliamentary committees and were brought to the Court's attention by a number of interveners. ${ }^{37}$

Although it expressly recognized these flaws, the Supreme Court went on to note that members of the UK Special Immigration Appeals Commission have "commented favourably on the assistance provided by special advocates" and that English courts have similarly endorsed this model. ${ }^{38}$ By relying on the rulings of English courts on the matter, and ignoring the views of special advocates and parliamentary committees, the Court was making at least one of two statements. First, international human rights against which the UK model runs have no binding force on Canada and so are norms the government may, but is not obligated to, respect. It is true that the pronouncements of the ECHR and the norms of the European Convention of Human Rights are not binding on Canada. However, we are bound to respect the rights of Convention refugees and the terms of $C A T$, two sources of law that formed part of the principled base upon which the ECHR rested its ruling. Insofar as the UK's system and security certificates have analogous effects on affected persons, the ECHR's ruling is, I think, about as relevant and persuasive as a judgment can possibly be and certainly indicative of what are Canada's international legal obligations. Insofar as this is so, it was incumbent on a court that claims to take international law seriously to more thoroughly work through the ways in which the UK's legislative response failed to meet international human rights standards. Second, the Court tried to avoid this by suggesting that the opinions of the English judiciary are compelling pronouncements on the compatibility between the UK system and international human rights. The "views" of their legislative committees, civil society groups, and special advocates, by contrast, are moral or political in nature and do not stand up nearly as well as relevant and persuasive sources of insight.

The Court's dismissal of a range of persuasive international human rights perspectives highlights the qualitative difference between international human rights and constitutional rights, even if the two are at times closely intertwined. It also demonstrates that the Charter does not

(C) Graham Hudson, 2009. This open-access work is licensed under a Creative Commons Attribution-NonCommercial 4.0 International License, which permits use, reproduction and distribution in any medium for non-commercial purposes, provided the original author(s) are credited and the original publication in Refuge: Canada's Journal on Refugees is cited. 
provide levels of protection at least as great as that afforded by international law. ${ }^{39}$ Rather, international law may be used as an interpretive aid, but need not be enforced by Canadian courts. This suggests that international law functions much like foreign law, with the latter in this case determining judges' interpretation of the content, scope, and domestic relevance of international legal norms. All of this raises such questions as: What structures Canadian courts' use of international and foreign law? Does it matter whether external law is binding, or need it simply be relevant? How is relevance determined? Does this depend on law's genesis in judicial decree or express legislative enactments? While there are no ready answers to these questions, it is clear is that greater receptivity to international and foreign law does not by itself enhance the responsiveness of judgment to values of human dignity.

International and foreign law were also referenced during the Court's ss. 9 and 10(c) analysis. In addition to American case law, the Court cited article 5 of the European Convention on Human Rights and related case law in support of its finding that foreign nationals possess a statutory and common law right to "prompt review to ensure that their detention complies with the law." 40 Taking notice of the fact that permanent residents who allegedly pose a threat to national security are entitled to an automatic review within forty-eight hours of their detention and then again every six months, the Court ruled that there was no reason why foreign nationals should not be entitled to the same procedural protections. Given the obvious presence of reasonable alternatives consistent with the government's stated legislative objectives, the Court ruled that detention provisions pertaining to foreign nationals unjustifiably infringed ss. 9 and 10(c). International human rights, though cited, do not appear to have played a prominent role in the Court's identification of the right in question or in its assessment of whether the limitation of this right was justified. Instead, they served to add rhetorical force to a legal principle that was firmly anchored in Canadian law.

Subsequent references to international human rights facilitated the finding that security certificate and detention provisions do not violate ss. 12 and 15 . Counsel for Mr. Almrei argued that the security certificate scheme in general and the detention provisions in particular together transformed "the appellant's detention into one that is cruel and unusual." 41 In responding to this claim, the Court cited an ECHR judgment in which it was found that indefinite detentions in contexts where the detainee has no hope of release or recourse to effective legal processes may constitute cruel and unusual treatment. ${ }^{42}$

The Court concluded that IRPA is consistent with s. 12 of the Charter. Properly interpreted, IRPA provides detainees with hope of release and access to regular and "robust" detention reviews in which Federal Court judges are authorized to order conditional release. ${ }^{43}$ The Court did recognize that IRPA left judges considerable discretion as to how they would structure detention reviews and that they have generally "set a high standard for release." 44 It responded to these concerns by detailing a list of factors the consideration of which would facilitate the conditional release of more detainees. The factors to be considered are: reasons for detention; length of detention; reasons for delay in deportation; anticipated future length of detention; and alternatives to detention.

In rendering this aspect of its decision, the Court tried to justify why it took a different approach from that taken by the House of Lords in A and Others $v$. Secretary of State for the Home Department (Re A). ${ }^{45}$ In that case, seven of nine judges found that provisions mandating the indefinite detention of non-citizens for reasons of national security was discriminatory and hence violated article 14 of the European Convention on Human Rights. The House of Lords noted that, alongside immigration law provisions, the UK had effectively relied on anti-terrorism criminal law provisions which did not distinguish between citizens and non-citizens and which were supplemented with robust procedural safeguards. Since it could not be shown that non-citizens pose a greater threat than citizens, the House of Lords ruled that treating the former more harshly than the latter was discriminatory. The UK responded to this judgment in 2005 by replacing its certificate scheme with control orders that do not, strictly speaking, authorize indefinite detentions and which may be issued against both citizens and noncitizens. $^{46}$

The Supreme Court of Canada ruled that $\operatorname{Re} A$ is not relevant to Canadian law since the impugned provisions in that case provided for indefinite detentions, while IRPA, properly administered, does not. There is some force to this claim, since the UK cannot deport non-citizens when there are substantial grounds for believing they would face the risk of torture or similar abuse, even if such persons pose a serious threat to national security. ${ }^{47}$ To the extent that the government decides not to release a detainee, s/he will remain in detention indefinitely and for reasons unconnected to deportation. By virtue of the Court's ruling in Suresh v. Canada (Minister of Citizenship and Immigration), ${ }^{48}$ Canada may deport persons to face the substantial risk of torture or similar abuse under exceptional circumstances. Further, in light of the Court's ss. 9 and 10(c) ruling in Charkaoui I, IRPA provides even persons who cannot be deported a realistic chance of release as well as access to procedures in order to procure that release. This, the Court concluded, means that Canadian detainees do not face indefinite detention.

(C) Graham Hudson, 2009. This open-access work is licensed under a Creative Commons Attribution-NonCommercial 4.0 International License, which permits use, reproduction and distribution in any medium for non-commercial purposes, provided the original author(s) are credited and the original publication in Refuge: Canada's Journal on Refugees is cited. 
In its submission, the University of Toronto International Human Rights Clinic argued that detention provisions in Canada and the UK cannot be so easily distinguished. As mentioned, Canada still may not, except under exceptional circumstances, deport persons to face the substantial risk of torture or similar abuse. Insofar as judges adopt a narrow definition of what qualifies as exceptional circumstances, named persons who cannot be released for reasons of public or personal safety face the prospect of indefinite detentions. The Supreme Court was unwilling to recognize this, missing another opportunity to fully engage with, much less give effect to, Canada's international human rights obligations.

This left the appellants' s. 15 claim that IRPA's security certificate and detention provisions discriminate against non-citizens. The International Human Rights Clinic submitted that, as the UK had done for several years, Canada has responded to terrorist threats using both immigration law provisions and criminal law provisions. They further submitted that conduct which leads to findings of inadmissibility for reasons of security may also constitute an offence under Part II.1 of the Criminal Code of Canada. This being so, the Canadian government distinguishes between citizens and non-citizens when it might just as effectively proceed with criminal law provisions or even administrative law provisions applicable to citizens and non-citizens alike, as is currently done in the UK.

The International Human Rights Clinic's argument was curtly rejected in the course of three paragraphs, with the Court concluding that there was no evidence to show that detention provisions have been "unhinged from the state's purpose of deportation." 49 Missing was a robust analysis of whether IRPA's clear distinction on enumerated grounds constitutes discrimination, whether similar objectives could be pursued through criminal law provisions or through administrative law provisions which do not distinguish on the basis of citizenship, and what might be Canada's international human rights obligations as informed by UK case law. This latter omission is surprising, given the weight the Court accorded to English judicial opinion on the legality of the UK's special advocate system.

\section{What's the Difference? The "New" Provisions}

The government responded to Charkaoui I, and to the reports of three parliamentary committees, ${ }^{50}$ by overhauling the certificate regime. One of the more significant changes it made relates to the commencement of proceedings. Under the old provisions, judges were to consider the information and evidence upon which a security certificate was based in private for seven days. After this time, they provided named persons with a summary of the evidence, excluding evidence the disclosure of which would, in the judge's opinion, be injurious to national security or the safety of any person. Judges were also required to hold ex parte, in camera proceedings when hearing evidence the disclosure of which would, in her opinion, be similarly injurious. Under the new provisions, proceedings begin the instant a certificate is referred, while initial summaries are provided by the ministers and exclude evidence that, in their opinion, would compromise national security or personal safety. Further, judges are required to hold proceedings ex parte and in camera when hearing evidence the disclosure of which could be injurious to national security or the safety of any person. ${ }^{51}$ This is a change that lowers the burden the government must meet in order to exclude named persons from proceedings.

The weakening of procedural safeguards in these respects has to some degree been counterbalanced by provisions governing the powers and responsibilities of special advocates. Section 83(1)(b) states that a judge shall appoint a special advocate during any security certificate or detention review proceeding. Section 86 expands this right to other proceedings in which the government applies for non-disclosure of evidence. Section 83(10(b) requires judges to select special advocates from a list established by the Minister of Justice after hearing representations from both named persons and the minister, giving added weight to the preferences of the named person. However, s. 83(1.2) requires a judge to appoint a person specifically requested by a named person, unless such an appointment would result in unreasonable delays, there is a conflict of interest, or that person possesses knowledge the disclosure of which would be injurious to national security or the safety of any person and where there is a reasonable risk of inadvertent disclosure.

The role of special advocates is to protect the interests of named persons during secret proceedings. They perform this role by challenging the government's applications for non-disclosure as well as the relevance, reliability, sufficiency of, and weight to be accorded to undisclosed information. In carrying out these functions, special advocates are entitled to receive from the ministers any evidence that has been provided to reviewing judges but which is not provided to the named person. Using this evidence, special advocates may make oral and written submissions, participate in closed proceedings, cross-examine witnesses who testify, and, with judicial authorization, exercise any other powers necessary to protect the interests of the named person. ${ }^{52}$ Finally, the government is obligated to provide special advocates with "adequate administrative support and resources." 53 This last provision was included in response to the Court's observation that the lack of administrative support and resources for special advocates used to be one of the principal weaknesses of the UK model. It remains to be seen whether the term "adequate" will be interpreted

(C) Graham Hudson, 2009. This open-access work is licensed under a Creative Commons Attribution-NonCommercial 4.0 International License, which permits use, reproduction and distribution in any medium for non-commercial purposes, provided the original author(s) are credited and the original publication in Refuge: Canada's Journal on Refugees is cited. 
relative to the standards set by SIRC or to another, lower standard.

Although these provisions enhance the level of procedural protections afforded to named persons, the government's interest in secrecy is protected through a number of conspicuous limitations upon special advocates' powers. As in the UK's system, special advocates must apply for judicial authorization to subpoena documents or witnesses and to communicate with any person about a proceeding after having accessed secret evidence. ${ }^{54}$ As mentioned, these restrictions on communication and investigation seriously inhibit special advocates' capacity to protect the interests of named persons. Without the power to subpoena documents or witnesses, the ministers may withhold or even destroy information that is relevant to a named person's defence; the only information a special advocate or reviewing judge sees is that which supports the government's position. Without access to all relevant information, and without the ability to communicate with named persons throughout a proceeding, special advocates quite simply cannot fully assess the relevance, reliability, or sufficiency of submitted evidence; clarify misunderstandings or the negative implications of circumstantial evidence; submit contrary evidence the existence of which is known only by a named person or a select few others; or ask witnesses appropriate questions during cross-examinations.

These structural limitations are exacerbated by the fact that, under the new provisions, the ministers provide named persons with the initial summary of the information and evidence to be used against them. In the likely event that these summaries will be heavily redacted and lacking in useful information, named persons will be unable to effectively forecast what kinds of strategies their special advocates should adopt while the two are still permitted to communicate. In order to remedy this problem, special advocates will need to access the information and evidence that has been excluded from the initial summary, a power they have been given in their capacity as representatives during secret hearings. Of course, this means that they will be prohibited from communicating with named persons the instant they exercise this power.

The upshot of this arrangement is that named persons' right to be informed and their right to be heard have been disconnected from each other, with neither being adequately safeguarded. Given the existence of secret proceedings, the right to be heard can only be fully protected if special advocates are present in these proceedings. Prior to participating in secret hearings, special advocates can, of course, communicate with named persons and their legal counsel in order to review allegations, disclosed evidence, legal arguments, and general litigation strategies; in this way, they give a voice to named persons. However, named persons' right to be informed is improved beyond the usual provision of summaries only if special advocates effectively challenge the ministers' motions to keep contested evidence classified. This, in turn, depends in no small part on special advocates' ability to communicate with named persons on an ongoing basis which, it should be restated, does not require communication about the content of secret evidence. This is all to say that the rights to be informed and to be heard are mutually constitutive; the full realization of one requires the full realization of the other. Without ongoing communication-without a continuous cycle of information being received and communicated by named persons-the new provisions alone cannot effectively improve either named persons' right to know the case against them or their right to be heard.

Some of these problems could be bypassed if special advocates were authorized to subpoena documents and witnesses. With access to greater volumes of information, some of which may be exculpatory in nature, special advocates would be better positioned to challenge evidence against a named person. Ideally this information could be accessed prior to the commencement of secret proceedings. If not, it would still improve special advocates' understanding of the facts and context associated with the ministers' evidence. And, if it were decided in a secret hearing that the information could not be safely disclosed, the information could still be forwarded directly to named persons in summary form. Notwithstanding the fact the information may not ever reach a named person, enhanced access to information that is held but not submitted as evidence by the ministers would improve levels of adversarial challenge and, by implication, reviewing judges' ability to decide on the basis of the facts and the law.

Although the new provisions do not grant special advocates the power to communicate with named persons (or anyone else) during proceedings or the power to subpoena documents and witnesses, judges possess the discretion to offer these powers on a case-by-case basis. ${ }^{55}$ The new provisions share other, discretionary features of the UK model. As mentioned, Canadian special advocates may be disqualified from representing named persons if there is a risk of the inadvertent disclosure of personal knowledge when such disclosure would be injurious to national security or the safety of any person. ${ }^{56}$ In the UK, special advocates who possess knowledge of confidential information that pertains to a case at hand are prohibited from participating in that case without judicial authorization. Often, this occurs when special advocates acquire expertise in a certain geographical area, such as how terrorist networks operate in one or two specific countries. ${ }^{57}$ Once they possess knowledge of secret

(C) Graham Hudson, 2009. This open-access work is licensed under a Creative Commons Attribution-NonCommercial 4.0 International License, which permits use, reproduction and distribution in any medium for non-commercial purposes, provided the original author(s) are credited and the original publication in Refuge: Canada's Journal on Refugees is cited. 
facts, they may be disqualified from representing particular detainees on the grounds that the inadvertent disclosure of this knowledge may betray what information and contacts the government has. While this provision has a legitimate function, coupling it with a blanket prohibition on caserelated communications between even two special advocates (as is the case under the terms of IRPA) paralyzes networking among special advocates. Again, unlike the SIRC model, special advocates working in the context of IRPA are likely to operate more or less in isolation from each other and without being able to apply certain kinds of expertise.

Despite these negative observations, amendments to provisions governing arrests and detentions have integrated other, arguably more positive aspects of the UK model. Since Re A, the UK has replaced its security certificate system with control orders which fall under two types: those that derogate from the European Convention on Human Rights and those that do not. Non-derogating control orders impose restrictions upon, among other things, a person's movement, place of residence, communications with others, and access to means of communication such as cellular phones and the internet. The violation of these conditions is an offence punishable by imprisonment. So long as these restrictions cumulatively fall short of restricting liberty, as defined under article 5 of the European Convention on Human Rights, English courts have held that non-derogating control orders are consistent with international human rights. ${ }^{58}$

In similar fashion, the Canadian government has moved towards formally replacing indefinite or prolonged detention with conditional release. First, in response to Charkaoui I, the government has brought IRPA into compliance with ss. 9 and 10 (c) of the Charter by removing legislative distinctions between foreign nationals and permanent residents. Anyone who is arrested and detained is entitled to a review within forty-eight hours of the beginning of their detention and then again once within every six-month period until it is determined whether a certificate is reasonable. Second, named persons who remain in detention six months after a certificate has been determined to be reasonable may apply for a review of the reasons for continued detention. Judges are obligated to order the detention to continue if satisfied that release on conditions would be injurious to national security or endanger the safety of any person, or, if the named person is unlikely to appear at a proceeding or for removal. ${ }^{59}$ Interestingly, the old provisions had similar wording and, in the case of foreign nationals, the burden of demonstrating the need for continued detention lay upon the government. Finally, persons released under conditions may apply for another review of the reasons for continuing the conditions within six months of the preceding review.
Unlike violations of control orders, violations of the terms of conditional release are not criminal offences, but may result in the resumption of detention. In such an instance, detainees may continue to apply for review and for release under conditions in the usual way.

\section{Whither International Law? Charkaoui II}

Viewed in isolation, Charkaoui I is an ambivalent ruling that does not seem to support the hope that international law can improve levels of respect for non-citizens' rights in Canada. To be sure, the Court considered international legal norms to be relevant and persuasive sources of insight into the constitutional dimensions of security certificates. However, contrary to the normative values to which the relevant and persuasive doctrine is directed, the result seems to have been the limitation, rather than vindication, of named persons' rights. On the one hand, when international law was used, it was treated as no more authoritative than foreign law, with the two being merged in order to offer an alternative to reinstituting the SIRC model; this alternative raised levels of rights respect in certificate provisions, but only to the absolute bare minimum. On the other hand, international law was ignored when its use would have supported the provision of more expansive procedural protections or the dismantling of the certificate regime altogether. Nowhere to be seen were principles associated with the presumption of conformity doctrine or the presumption of minimal protection doctrine. Either of these doctrines would have forced the consideration of international human rights as authoritative legal norms notionally more binding than foreign law, while the latter might well even have required the government to provide more than the bare minimum of procedural protections required by the Court's reading of the Charter. By ignoring these doctrines, and the principles that underpin them, the Court was able to refine the certificate regime while leaving it more or less functionally intact.

However, Charkaoui I should not be viewed in isolation. Indeed, shortly following the amendment of the certificate regime, the Court did a surprising thing when it rendered its judgment in Charkaoui II; ${ }^{60}$ it chose to refine the amended certificate regime in such a way as to give effect to those international human rights standards it flat-out refused to enforce a year earlier. It did so by imposing upon the government a general duty to retain and disclose all information on file relevant to a named person to special advocates and reviewing judges, and by authorizing reviewing judges to forward such information as can safely be disclosed directly to named persons. ${ }^{61}$ The net effect of this ruling has been to compensate for special advocates' inability to subpoena documents and witnesses without reviewing judges having to grant these powers on a case-by-case basis. Now, 
all information on file that is relevant to a named person must be disclosed in every certificate proceeding; there is no need for special advocates to request documents on an ad hoc basis. With the assistance of special advocates and the ministers, reviewing judges are then responsible for deciding what information may safely be disclosed, what must be kept secret, and, of course, whether a certificate is reasonable or an unconditional detention is justified.

What is interesting about this case is that it helped remedy one of the most serious defects of the UK model without there being a single reference to either international law or the constitutionality of our special advocate system. The decision was predicated entirely on criminal law principles the application of which was justified on the basis of analogies between certificate proceedings and criminal law proceedings as well as between civilian intelligence agency and law enforcement agency activities. Yet, viewed within the broader, post-9/11 transformation of the security certificate regime, and Canadian national security law and policy most generally, this decision was without a doubt steeped in international perspectives. The Court was acutely aware of how Canadian national security agencies have been sharing intelligence with foreign and international national security agencies in flagrant disregard for principles of privacy, fairness, and public review. ${ }^{62}$ This consciousness may be inferred from facts that: the expanded integration of Canadian national security agencies with those of foreign countries is a conspicuous component of our post-9/11 national security policy; ${ }^{63}$ the issues raised in Charkaoui II related to information CSIS subsequently acquired (but did not disclose) from Moroccan authorities and that contributed to the issuance of a Moroccan arrest warrant against Mr. Charkaoui; and the Court cited excerpts from Justice Dennis O'Connor's report on Maher Arar, which details the extents to which Canada participates in unregulated global intelligence agency coordination. ${ }^{64}$ Finally, the Court recognized that CSIS's intelligence is used to facilitate the deportation of named persons to face the serious risk of human rights abuses abroad. ${ }^{65}$

Given Canada's role in international counterterrorism practices, and the kinds of impacts this has on the well-being of named persons, the Court ruled that weightier criminal law principles of disclosure must be applied to certificate proceedings. Reviewing judges have since required the government to disclose to special advocates thousands of pages of previously classified intelligence. ${ }^{66}$ Initially, the ministers had redacted significant portions of this information based on their consideration of relevance and privilege, including "covert human intelligence source privilege." 67 On March 12, 2009, the Federal Court lifted most redactions made to sixty-seven contested documents. ${ }^{68}$ On the opposite side of the spectrum, the Federal Court later ruled that special advocates are only entitled to such information as is "necessary to examine and verify the accuracy of the information submitted." 69 Setting the threshold of what information is relevant to "necessary" raises the bar well beyond the "reasonable possibility" test stipulated in criminal law. ${ }^{70}$

Still, on the whole, Charkaoui II has effectively compensated for the absence of legislative provisions granting special advocates the power to access all information in the government's possession and to subpoena documents and witnesses, ${ }^{71}$ two core weaknesses with the UK model. Principles of disclosure enunciated in this case have since also been interpreted by lower courts to enable special advocates to communicate with each other about confidential information, again compensating for restrictive legislative language in this respect. ${ }^{72}$ While the Supreme Court did not strike down or rewrite legislative provisions in this case, it encouraged lower court judges to exercise their legislatively mandated discretion to bring certificate provisions more closely in step with international human rights standards that were note given effect in Charkaoui I.

\section{Concluding Remarks}

International human rights have considerable appeal as instruments well suited for the protection of non-citizens' rights in Canada. They have proven to be particularly attractive in the context of security certificates because they inhere within individuals irrespective of personal characteristics, national political boundaries, or the exigencies of public policy. As with all immigrants, persons named in security certificates have traditionally been denied the equal protection of Canadian constitutional law because they are not citizens and because judges have often accepted that national security concerns can justify the limitation of their human rights. Charkaoui I and II signal a marked shift in judicial attitudes about the rights to which named persons are entitled and about the proper balance between national security and human rights, a shift that has been influenced by international legal perspectives generally.

However, the precise nature and scope of international law's influence has been highly ambiguous and ambivalent. In Charkaoui I, the Supreme Court of Canada's interpretation of international law and foreign law encouraged the deeper integration of a flawed, foreign-based regime into Canadian national security law and policy. Yet, it chose to ignore international human rights perspectives critical of that regime and it chose not to require the reinstitution of elements of a traditional domestic regime that would have improved levels of disclosure, fairness, and adversarial challenge. No justification was given for why one set of international legal norms was recognized and the other disregarded, nor why foreign

(C) Graham Hudson, 2009. This open-access work is licensed under a Creative Commons Attribution-NonCommercial 4.0 International License, which permits use, reproduction and distribution in any medium for non-commercial purposes, provided the original author(s) are credited and the original publication in Refuge: Canada's Journal on Refugees is cited. 
law should be given greater weight than those international human rights Canada is obligated to respect. Finally, no justification was offered for why international or foreign law should have been used at all when there existed ample domestic resources for improving the constitutional defects of the certificate regime. In fact. international and foreign law here served as a way to escape the reinstitution of this regime, along with its comparatively robust procedural protections. To make matters even worse, the Court chose not to use international law at all in Charkaoui II, even though the facts and issues of the case directly engaged Canada's role in international counterterrorism practices.

These cases may be evaluated in a wide number of ways. Skeptics will doubtless see in them all that is wrong with our law of reception, and perhaps even with constitutional adjudication as an avenue towards achieving greater social justice. We see in these rulings nothing more than the judiciary's clumsy attempt to use whatever tools were available to achieve the results they wanted. What is given in one case can be taken away in another, leaving named persons and government bodies alike in the dark concerning precisely what are their rights and obligations. And, at the end of the day, the desired result seems to have been the preservation of an arguably discriminatory regime that both submits and exposes non-citizens to a litany of human rights abuses. While not the cause, international and foreign law played no small role in rationalizing the reconstitution of this regime.

Yet, an alternative view is equally plausible: one that reformulates the results the Court was looking for, although not the means. One might hypothesize that the Court from the very beginning was persuaded by the international human rights arguments submitted by Mr. Charkaoui, Mr. Almrei, Mr. Harkat, and those intervening on their behalf. However persuasive these arguments may have been, a range of practical problems precluded the issuance of a judgment to that effect. The government had, after all, firmly declared its intention to deconstruct the SIRC regime and was committed to using the powerful rhetoric of (inter) national security to insulate certificate proceedings and associated practices from meaningful parliamentary and judicial review, two powerful, policy-oriented bases upon which to argue for judicial deference. The Court was also acutely aware that judge-led attempts to strike better balances between national security and human rights in other jurisdictions had proven to be quite ineffective. In the UK, for instance, the House of Lords relied on international human rights in finding that the UK's version of security certificates unjustifiably discriminated against non-citizens and was therefore illegal. ${ }^{73}$ The UK government responded by replacing the impugned regime with one that permitted the targeting of both citizens and non-citizens. ${ }^{74}$ From its perspective, the problem of discrimination had been solved and, in one sense, international human rights were given effect. But this effect was purely symbolic and painfully ironic; the well-being of those caught up in national security machinery was effectively compromised as a result. The point had been missed.

This in mind, the Supreme Court of Canada had a choice: to issue a decision that formally consisted with available international human rights norms or to issue a decision that was more likely to give practical effect to those norms in the long run. By recommending the further entrenchment of a flawed, foreign-based certificate regime in Charkaoui $I$, it opted for the latter. Although symbolically the decision was conservative if not outright apologetic, it left open the possibility of progressively infusing into this system those international human rights standards that likely could not be given practical effect at first instance. This progressive infusion is precisely what occurred in Charkaoui II, whereby many of the international human rights standards that the Court seemed to disregard a year earlier were grafted onto the regime through the exercise of judicial discretion. Following Charkaoui II, certificate proceedings (but not certificate provisions) have been characterized by expanded levels of disclosure, fairness, and adversarial challenge. Persons named in security certificates have accordingly been far better positioned to defend themselves and, in fact, Mr. Charkaoui successfully relied on the principles enunciated in Charkaoui II to secure his unconditional release in October $2009 .{ }^{75}$ With Hassan Almrei having won his freedom in December 2009, ${ }^{76}$ it would not be unreasonable to speculate that the certificate regime is facing an existential threat.

It may be said that international law need not have played a role in this process at all; the Court might simply have had its eyes fixed on gradually reinstating the SIRC model. But even here, international law served as a highly useful means of realizing that end. Given our courts' outright refusal to recognize certificate provisions as unconstitutional prior to Charkaoui I, international legal and political developments post-9/11 were also critical variables affecting changes in judicial attitudes towards the rights to which non-citizens are entitled. The point is not that international law determined these decisions one way or another, but that the global dimensions of certificate proceedings and of Canadian national security law and policy have required judges to consider international legal norms as reasons for deciding in one way and not the other.

All things considered, it is best to take a modest view of the impact of international law on judicial reasoning in general and the development of our certificate regime in particular. If nothing else, Charkaoui I, Charkaoui II, and their

(C) Graham Hudson, 2009. This open-access work is licensed under a Creative Commons Attribution-NonCommercial 4.0 International License, which permits use, reproduction and distribution in any medium for non-commercial purposes, provided the original author(s) are credited and the original publication in Refuge: Canada's Journal on Refugees is cited. 
aftermath highlight that judicial decrees and legislative enactments reflect a complex arrangement of conflicting perspectives, values, and expectations that do not dissipate once a ruling is handed down. Courts must anticipate and respond to as many of these forces as possible if their decisions are to be both authoritative and effective. Even in cases that are thoroughly global in nature, international law is just one among many resources that help judges perform this task. As unsatisfying as the amended certificate provisions are from the perspective of international human rights, they constitute the system within which special advocates and others must work. What matters now is how various actors perform within the often tedious and unglamorous phases of day-to-day practice and decision-making. Will Canadian courts decide to continue using their discretionary authority to shape certificate proceedings in the image of international human rights, or are the new provisions nothing more than their way of casting a thin veneer of legality over an essentially arbitrary process? As with anything else, we will just have to wait and see.

\section{Notes}

1. [2007] 1 S.C.R. 350.

2. Canada (Minister of Employment and Immigration) $v$. Chiarelli, [1992] 1 S.C.R. 711; Charkaoui v. Canada Minister (Citizenship and Immigration), [2004] 3 F.C.R. 32; Charkaoui v. Canada Minister (Citizenship and Immigration), [2004] 1 F.C.R. 528.

3. R.S.C. 2001, c. 27

4. An Act to amend the Immigration and Refugee Protection Act (certificate and special advocate) and to make a consequential amendment to another Act, S.C. 2008, c. 3, ss. 83-87, amending Immigration and Refugee Protection Act, S.C. 2001, c. 27, Part 1, Division 9.

5. Charkaoui I, supra note 1 at para. 83. The Court cited a UK parliamentary report that included extensive consideration of international law; United Kingdom, House of Commons, Report of the Constitutional Affairs Committee, The operation of the Special Immigration Appeals Commission (SIAC) and the use of Special Advocates (March 2005). As I will detail below, numerous interveners also drew the Court's attention to the ways in which the regime fell below international human rights standards.

6. Charkaoui v. Canada (Citizenship and Immigration), [2008] 2 S.C.R. 326

7. The Minister of Public Safety and Emergency Preparedness is now styled the Minister of Public Safety; the Minister of Citizenship and Immigration is now styled the Minister of Citizenship, Immigration and Multiculturalism.

8. References to IRPA throughout this section will be to the Act in force between December 12, 2006, and February 21, 2008. Immigration and Refugee Protection Act, supra note
3, s. 77(1). I also speak in the past tense throughout this section, although some of the provisions cited are still in force.

9. Ibid., s. 82(1)(2).

10. Ibid., s. 81(1)(2)

11. IRPA, supra note 3 , ss. 83 and 84 .

12. Ibid., ss. 78 (c) and $78(\mathrm{j})$.

13. Ibid., s. 78 (e).

14. Adil Charkaoui, for instance, was made subject of an arrest warrant in his home country of Morocco after he was detained through a security certificate. A number of independent reports on Morocco issued in 2004 highlight the regular use of torture and similar abuse, deplorable prison conditions, indefinite detentions, targeting of Muslims and other racialized minorities, excessive and unregulated use of emergency legislation, the lack of adequate legal representation for persons charged with broadly defined terrorismrelated offences, the lack of due process, and the lack of an independent judiciary; see Human Rights Watch, "Human Rights at a Crossroads" (October 2004) 16:6(E), online: Human Rights Watch <http://www.hrw.org/reports/2004/ morocco1004/> (accessed 30 May 2009); Human Rights Committee, $82^{\text {nd }}$ Session, "Concluding observations of the Human Rights Committee: Morocco" (CCPR/CO/82/ MAR1), 1 December 2004 at paras. 10, 14m 15-17, 19-21. For a more recent report, see Amnesty International, Annual Report 2009, online: Amnesty International $<$ http://report2009.amnesty.org/en/regions/middle-eastnorth-africa/morocco > (accessed 30 May 2009).

15. Chiarelli, supra note 2; Charkaoui supra note 2.

16. IRPA, supra note 3 , ss. 78 (h) and 78 (i).

17. Convention relating to the Status of Refugees, 28 July 1951, 189 U.N.T.S. 150, Can. T.S. 1969/6 (entered into force 22 April 1954, accession by Canada 2 September 1969), Arts 1(F), 33. For the Supreme Court's ruling on national security-based deportations to face the reasonable risk of human rights abuses, see Suresh v. Canada (Minister of Citizenship and Immigration), [2002] 1 S.C.R. 3.

18. IRPA, supra note 3 , ss. 79 and 81 (c).

19. Ibid., s. 3(2)(h).

20. James Nafziger, "The General Admission of Aliens under International Law" (1983) 44 American Journal of International Law 804.

21. See, for example: United Nations Security Council, $4385^{\text {th }}$ Meeting, "Resolution 1373 (2001)" (S/RES/1373). 28 September 2001; United Nations Security Council, $4956^{\text {th }}$ Meeting, "Resolution 1540 (2004)" (S/RES/1540 ). 28 April 2004; United Nations Security Council, 5261 ${ }^{\text {st }}$ Meeting, "Resolution 1624 (2005)" (S/RES/1624), 14 September 2005.

22. Convention Against Torture and Other Cruel, Inhuman or Degrading Treatment or Punishment, 10 December 1984, 1465 U.N.T.S. 85, Can. T.S. 1987 No. 36.

23. The United Kingdom and South Africa, for instance, have respectively used statutory and constitutional provisions

(C) Graham Hudson, 2009. This open-access work is licensed under a Creative Commons Attribution-NonCommercial 4.0 International License, which permits use, reproduction and distribution in any medium for non-commercial purposes, provided the original author(s) are credited and the original publication in Refuge: Canada's Journal on Refugees is cited. 
to clarify their laws of reception. See: The Human Rights Act (U.K.), 1998, c. 42; Constitution of the Republic of South Africa Act 108 of 1996, ss. 39, 233.

24. Re Arrow River and Tributaries Slide and Boom Co. v. Pigeon Timber Co., [1932] 2 D.L.R. 250 (S.C.C.); In the Matter of a Reference as to the Powers of the Corporation of the City of Ottawa and the Corporation of the Village of Rockcliffe Park to Levy Rates on Foreign Legations and High Commissioner's Residences, [1943] S.C.R. 208; Daniels v. R., [1968] S.C.R. 517; National Corn Growers Assn. v. Canada (Import Tribunal), [1990] 2 S.C.R 1324; Pushpanathan v. Canada (Minister of Citizenship and Immigration) (1988), 160 D.L.R. (4 $\left.{ }^{\text {th }}\right) 193$ (S.C.C.); Baker v. Canada (Minister of Citizenship and Immigration), [1999] 2 S.C.R. 817.

25. Reference Re Public Service Employee Relations Act (Alberta), [1987] 1 S.C.R. 313 at 348-349. Dickson C.J. made the same statements regarding section 1 of the Charter in Slaight Communications Inc. v. Davidson, [1989] 1 S.C.R. 1038 at 1056-1057.

26. Gibran van Ert, Using International Law in Canadian Courts (The Hague, London, \& New York: Kluwer Law International, 2002) at 253-254.

27. There are a wide variety of ways of unpacking this general claim. A few examples include: Craig Scott, “Transnational Law' as Proto-Concept: Three Conceptions” (2009) 10:7 German Law Journal 877; Reem Bahdi, "Globalization of Judgment: Transjudicialism and the Five Faces of International Law in Domestic Courts" (2006) 34:3 George Washington International Law Review 555; Mayo Moran, "Authority, Influence and Persuasion: Baker, Charter Values and the Puzzle of Method" in David Dyzenhaus, ed., The Unity of Public Law (Oxford: Hart Publishing, 2004); Stephen J. Toope \& Jutta Brunnee, "A Hesitant Embrace: Baker and the Application of International Law by Canadian Courts" in David Dyzenhaus, ed., The Unity of Public Law (Oxford: Hart Publishing, 2004) 357; Karen Knop, "Here and There: International Law in Domestic Courts" (2000) 32 New York University Journal of International Law and Politics 501.

28. See, for instance, R. v. Hape, [2007] 2 S.C.R. 292. See also Graham Hudson, "Neither Here Nor There: The NonImpact of International Law on Judicial Reasoning in Canada and South Africa" (2008) 21 Canadian Journal of Law and Jurisprudence 322; Stephen J. Toope, "Keynote Address: Canada and International Law," in The Impact of International Law on the Practice of Law in Canada. Proceedings of the $27^{\text {th }}$ Annual Conference of the Canadian Council on International Law, Ottawa October 15-17, 1998 (The Hague: Kluwer Law International, 1999) 33.

29. Anne F. Bayefsky, International Human Rights Law: Use in Canadian Charter of Rights and Freedoms Litigation (Toronto \& Vancouver: Butterworths, 1992).

30. Scott, supra note 27; Craig Scott \& Phillip Alston, "Adjudicating Constitutional Priorities in a Transnational Context: A Comment on Soobramoney's Legacy and
Grootboom's Promise" (2000) South African Journal of Human Rights 206; Anne-Marie Slaughter, "A Typology of Transjudicial Communication" in Thomas Franck \& Gregory H. Fox, eds., International Law Decisions in National Courts (Irvington-on Hudson, NY: Transnational Publishers, 1996) 37.

31. Charkaoui I, supra note 1 at paras. 28-29.

32. For a detailed description of how the SIRC system worked, see Murray Rankin, "The Security Intelligence Review Committee: Reconciling National Security with Procedural Fairness" (1990) 3 Can. J. Admin L. \& Prac. 173.

33. Craig Forcese \& Lorne Waldman, Seeking Justice in an Unfair Process: Lessons from Canada, the United Kingdom and New Zealand on the Use of "Special Advocates" in National Security Proceedings, online: University of Ottawa $<$ http://aix1.uottawa.ca/ cforcese/other/sastudy.pdf>, at pp. $7-10$.

34. Chahal v. United Kingdom, (1997) 23 E.H.R.R. 413, [1996] Eur. Ct. H. R. 54.

35. Charkaoui I, supra note 1 at para. 83 .

36. Forcese \& Waldman, supra note 33 at 48.

37. United Kingdom, House of Commons, Constitutional Affairs Committee, supra note 5 at 33; United Kingdom, House of Commons and House of Lords, Joint Committee on Human Rights, "Review of Counter-terrorism Powers: Eighteenth Report of Session 2003-2004” HL 158, HC 713 (4 August 2004), at para. 41.

38. Charkaoui I, supra note 1 at para. 84 .

39. Some argue that the Charter should be interpreted in just this way; see van Ert, supra note 26 at 253-54, 269.

40. Charkaoui I, supra note 1 at para. 90.

41. Ibid., at para. 90.

42. Soering v. United Kingdom [1987] Eur. Ct. H. R. 88.

43. Charkaoui I, supra note 1 at para. 123.

44. Ibid., at para. 101.

45. [2004] U.K.H.L. 56.

46. Prevention of Terrorism Act (U.K.), 2005 c. 2.

47. Chahal, supra note 34 at para. 107. The UK has respected this decision.

48. Supra note 17.

49. Charkaoui I, supra note 1 at para. 131 .

50. House of Commons, Report of the Standing Committee on Public Safety and National Security, Rights, Limits, Security: A Comprehensive Review of the Anti-terrorism Act and Related Issues (March 2007); Senate, Report of the Special Senate Committee on the Anti-terrorism Act, Fundamental Justice in Extraordinary Times (February 2007); House of Commons, Report of the Standing Committee on Citizenship and Immigration, Detention Centres and Security Certificates (April 2007).

51. References to IRPA throughout this section will be to the Act in force since June 18, 2008. Immigration and Refugee Protection Act, supra note 3, s. 83(1)(c).

52. Ibid., ss. 85.2 and $85.4(1)$.

53. Ibid., s. 85(3). 
54. Ibid., ss. 85.2 (c) and 85.4(2).

55. Ibid., s. 85.2 (c). This section states that judges may grant special advocates "any other powers that are necessary to protect the interests" of named persons.

56. Ibid., s. 83(1.2)(b)(c).

57. Forcese \& Waldman, supra note 33 at 40.

58. Secretary of State for the Home Department v. MB (FC) [2007] U.K.H.L. 46.

59. Immigration and Refugee Protection Act, supra note 3, s. 82(5).

60. Charkaoui, supra note 6.

61. Ibid., at para. 2.

62. Ibid., at paras. 25-28, 47, 54 .

63. Canada. Privy Council Office, Securing an Open Society: Canada's National Security Policy (Ottawa: Queen's Printer, 2004); The global coordination of Canadian national security agencies is largely directed by the Integrated Threat Assessment Centre; online: Integrated Threat Assessment Centre, $<$ http://www.itac-ciem.gc.ca/index-eng.asp $>$ (accessed 30 May 2010).

64. Canada, Parliament, Report of the Events Relating to Maher Arar: Analysis and Recommendations (Ottawa: The Commission of Inquiry into the Actions of Canadian Officials in Relation to Maher Arar, 2006). See also, International Commission of Jurists, "Assessing Damage, Urging Action: Report of the Eminent Jurists Panel on Terrorism, Counter-Terrorism and Human Rights" (Geneva, 2009) at 67-73.
65. Charkaoui II, supra note 60 at para. 54 .

66. See, for instance, Harkat (Re), (2009) F.C. 340 at para. 7.

67. Ibid., at para. 7 .

68. Ibid., at para. 9.

69. Harkat (Re) (2009), F.C. 203 at para. 12

70. $R$ v. Stinchcombe, [1991] 3 S.C.R. 326.

71. Special advocates have not, however, been often granted requests to cross-examine government witnesses; see Harkat (Re) (2009), F.C. 204.

72. Harkat (Re) (2009), F.C. 59. It should also be noted that similar changes have been made in the UK; see Craig Forcese, National Security Law: Canadian Practice in International Perspective (Toronto: Irwin Law, 2008) at 414.

73. Re A, supra note 45 .

74. Counter-Terrorism Act (U.K.), 2008, c. 28.

75. Charkaoui (Re) (2009), F.C. 1030.

76. Almrei (Re) (2009), F.C. 1263.

Graham Hudson is an assistant professor in the Department of Criminal Justice and Criminology at Ryerson University and $a$ Ph.D. candidate at Osgoode Hall Law School, York University. He has acquired an LL.M. from Queen's University, a J.D. from the Faculty of Law, University of Toronto, and a B.A. (honours) in history and philosophy from York University. His research interests include security studies, immigration and refugee law, legal theory, and human rights. 